\title{
Diversity Management: Seeking Validation
}

M. Tony Bledsoe, Meredith College, USA

Rebecca J. Oatsvall, Meredith College, USA

David Condon, University of South Carolina, USA

\begin{abstract}
Diversity management is widely valued in higher education today, but closer examination often reveals a lack of action to support the level of diversity that institutions claim to embrace in many of their strategic documents. This paper includes an assessment of diversity management within South Carolina's technical colleges and an examination of survey results. It is a companion study to a prior study of diversity in North Carolina Independent Colleges and Universities (NCICU). The purpose of that research was to review campus-wide documents and structure of schools in the NCICU to determine diversity transparency (Bledsoe/Oatsvall).
\end{abstract}

Keywords: diversity management, technical colleges, structure

\section{INTRODUCTION}

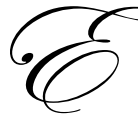

very university in this country should have a vice president of equity and diversity. There is no administration on any campus in America that will not say to you that they care about this issue and are committed to dealing with it. But you need to go the next step and create an irreplaceable structure that allows you to stay diligent. (Alhadeff, K., Chairman of the Washington State University's Board of Regents, as cited in Gose 2006)

Diversity management is "a strategy to promote the perception, acknowledgment and implementation of diversity in organizations and institutions" (University of Vienna, 2007). A central concern of diversity management is ensuring that it is both visible and effective. Diversity management is a widely acknowledged practice in higher education today. One issue is whether policies and practices reflect real substance or mere form at the institutions surveyed (Bledsoe \& Oatsvall, 2007). An initial step of this study was to examine the extent to which diversity is a priority among the technical colleges in South Carolina and then to review the policies or practices that have been adopted as tangible evidence of such commitments. This work parallels a study conducted by Bledsoe and Oatsvall (2008) of diversity management among private, independent colleges and universities in North Carolina. (See Appendix $\mathrm{C}$ for results of that survey.)

\section{LITERATURE REVIEW}

Garcia and colleagues (2002) defined "diversity" in higher education as educational activities that are campus-based and include students from all backgrounds. The goal is to enhance the educational experience of all students and they argue that each institution should define for itself the meaning of diversity. Research strongly suggests that diversity management in higher education delivers important benefits to students, institutions, and the communities in which they live. Such benefits include enhanced cognitive and critical thinking skills. Students immersed in diversity courses and diverse campus environments are more likely to recognize inequality, act on resolving it, and are more open to living in racially diverse neighborhoods after graduation (Garcia, Hudgins, Musil, Nettles, Sedlacek, \& Smith, 2002).

Milem, Chang, and Antonio (2005) found that "diversity-related benefits are far ranging, spanning from individual students and the institutions in which they enroll to private enterprise, the economy, and the broader society" (page 5). They further noted that three common themes emerge in literature reviews of diversity management: 
1. When educated in diverse settings, students are far more likely to live and work in racially and ethnically diverse communities after they graduate.

2. Individuals who study and discuss issues related to race and ethnicity in academic courses and who interact with a diverse set of peers in college are better prepared for life in an increasingly complex and diverse society.

3. Increasing the compositional diversity of the student body is essential to creating a diverse learning environment.

These authors go on to argue that campus leaders must "create conditions to maximize the learning and democratic outcomes associated with being educated in racially and ethnically diverse environments" (p.13). To do that, institutional leaders have to think strategically in developing policies and procedures aimed at maximizing the educational benefits of diversity. Milem, Chang, and Antonio conclude that "assessment of current efforts to institutionalize diversity on campuses suggests that most campus leaders have fallen well short of his goal..." (p. 13).

Analyzing various models of diversity management in corporate, education and other environments, Bledsoe and Oatsvall (2007) concluded that the academic model is predominately a structural approach. They observed that "this model tends to reflect organizational values and beliefs which are consistent with desirable and identifiable diversity management outcomes." Students are a major constituency of academic institutions but not reflected in the organizational chart. Astin (1996) suggests that assessment is based on and driven by institutional values. It is possible that some institutions, while claiming to value diversity, do not reflect this value in their organizational structure. The objective of this study was to identify which of South Carolina's technical colleges profess a commitment to diversity management and analyze the extent to which they have supported it with action, demonstrating how much the institution truly values diversity.

An effective diversity management should permeate all areas of institutional life. Statements of support, purpose and action from top campus leadership are good first steps in signaling an institution-wide commitment to diversity. These documents help establish principles for imbedding diversity into higher education. Strategies set forth goals leading to creation of an open, safe environment for interaction among groups and for diversifying the curriculum, faculty, staff and student body. They can also be the cornerstone for initiatives that signal to students in a tangible way that commitment to diversity is strong and proactive. The institution's stakeholders can also use these statements to hold leaders accountable for fulfilling diversity-related promises (Milem, Chang, and Antonio, $p$. 23). Desdemona Cardoza, Provost and Vice President for Academic Affairs at California State University at Los Angeles, suggests that "excellence" in education must be explicitly defined to include diversity in all areas of college life (2007).

Some organizations have acted to promote diversity from a defensive posture. That is, they appear to be motivated as much by an attempt to avoid controversy or litigation as by a desire to embrace diversity management. Bledsoe and Oatsvall (2008) point to institutional statements favoring diversity management that are not backed up by corresponding action as examples of true, if disappointing, organizational structure. In the academic arena, some institutions have followed this corporate mentality, leading to preferential treatment for minorities in admission decisions and hiring of faculty and staff. As Bledsoe and Oatsvall further point out, colleges and universities have three distinct constituencies in students, faculty, and staff. Their different needs and interests can help promote diversity through a variety of methods. This can create disparate and sometimes conflicting approaches to--and results from--diversity management.

Some educational institutions have created formal diversity positions in response to U.S. Supreme Court rulings in 2003 that cited educational benefits of diversity, thus allowing the University of Michigan to use race in admissions decisions (Gose, 2006). Steve O. Michael, vice provost for diversity and academic initiatives at Kansas State University, compiled a database of those who oversee diversity efforts at various colleges and universities. The list includes over 400 names, of which 80 are estimated to be chief diversity officers - meaning that they have titles such as vice president or vice provost (Gose, 2006). More recently however, the State of Michigan has adopted laws prohibiting the use of discrimination or preferential treatment in education (Schmidt, 2007). The goal may remain equal treatment for all citizens under the law, but the pathway is anything but clear and straightforward. Gose noted 
that some critics of racial preferences question the appropriateness of allowing diversity officers to measure the educational benefits of diversity. That specific task may be better done by an official who does not have a vested interest in the assessment of diversity outcomes. Some diversity advocates also question the effectiveness of chief diversity officers in the area of faculty hiring. "The chief diversity officer is going to bump up against the process for the hiring and promotion of faculty. That is a sacred process" (Gose, 2006).

\section{DATA COLLECTION/METHODOLOGY}

The colleges selected for this preliminary study are members of the South Carolina Technical College System. There are 16 colleges varying in size and location. They serve all 46 counties in the state and enroll over half of all undergraduates attending a public college or university in South Carolina. (South Carolina Technical College System.) (http://www.scteched.tec.sc.us.) These are listed in Appendix A.

The first step was to survey each institution to determine diversity-specific information. The best resource for collecting diversity information at the college was determined to be the person in change of Human Resources. To expedite the response process and to provide anonymity for the respondents, the survey was conducted online. Respondents were informed that if they wished to receive copies of the results, they could e-mail the researchers to request that information. The survey was sent out during the first week of May, 2008. The results were gathered during May and June 2008.

Attachment B is a copy of the survey. It primarily focused on whether diversity is referenced in mission statements, published goals, academic catalogs, or recruiting materials. Additional information was gathered about committee structure, curriculum, diversity training, and diversity policies. Each college was asked to provide its definition of diversity and to identify whether diversity is supported by its organizational structure.

The next step in data collection was to examine each college's website to see if the homepage and available documents reference diversity. Specific attention was paid to any institutional definition of diversity as well as any evidence that the institution supported diversity efforts.

\section{FINDINGS}

Responses were received from ten of the sixteen technical colleges surveyed, for a $62.5 \%$ response rate. The reporting format for the findings/implications generally follows the order of the survey questionnaire explaining those results provided by the respondents.

The college response to a question asking if diversity is referenced on their homepage shows $70 \%$ yes; $30 \%$ no. This indicates that these institutions understand the importance of reflecting their commitment to diversity in their public presence.

Response to the question about the inclusion of diversity in the college mission statement shows $60 \%$ yes; $40 \%$ no. This is less than the percentage referencing diversity on their homepage.

All respondents to the survey had published institution-wide goals and $60 \%$ of them had diversity as a major goal. This is consistent with the responses to the question concerning diversity in the college mission statement.

While assessment has become an integral part of college administrative procedures, only $60 \%$ of the institutions had assessment techniques in place for measuring diversity goal effectiveness. Even though this percentage seems low, it is consistent with prior answers that only $60 \%$ of the schools had diversity as a major goal. It appears that all institutions with diversity as a major goal were assessing their effectiveness in meeting that goal.

The Academic Catalog of an institution is one of the ways that it conveys its values. In response to the question about inclusion of a statement about diversity in the academic catalog, 70\% answered yes. Recruitment materials also reflect values held by a college and $78 \%$ of the community colleges responding to the survey indicated that their recruiting materials included diversity information. 
If an institution is to validate its avowed intent, those values should be reflected in its organizational structure. Only $40 \%$ of respondents indicated that they have a formal diversity group at their institution. Of those responding that they did have such a group, none had a student representative serving on the diversity committee.

Academic requirements are another way to assess the importance an institution places on diversity and diversity training. For example, only one institution has a specific diversity course in its academic curriculum and it is not a requirement of all students at that institution.

Diversity training is offered at some institutions for students, faculty and staff. Respondents indicated that $30 \%$ offered training for students, while $80 \%$ offered training for faculty and staff.

Of the institutions surveyed, $44 \%$ had a diversity policy in their Student Handbooks and $50 \%$ had a diversity policy in Faculty and Staff Handbooks.

Some organizations have indicated their commitment to diversity programs by naming a designated Director for Diversity Programs. Of the institutions responding, the percentage having such a person was the same (40\%) for students, faculty and staff.

\section{COMPARISON TO PRIOR STUDY}

The schools surveyed in our prior study (NC Independent Schools and Colleges) showed both similarities and differences with the schools surveyed for this project (SC Technical Schools). Differences may be partially accounted for by the nature of the institutions. The North Carolina group is made up of four year private colleges while the South Carolina group is made up of publicly funded technical schools. Both groups of schools primarily serve traditionally aged college students, most of whom are from the state in which they are attending college.

A college's homepage is frequently the first place that perspective students visit to assess their compatibility with a school. Of the NC private schools, only $30.8 \%$ mentioned diversity on their homepage, while of the SC technical schools, $70 \%$ of the homepages referred to diversity. Published institution-wide goals generally included diversity at both groups (60\% for SC and 54.5\% for NC schools). Another important source of information is the school's Academic Catalog. Seventy percent of SC technical schools and $61.5 \%$ of the NC schools surveyed included a statement about diversity in their academic catalogs. Undergraduate recruiting materials referred to diversity in $69.2 \%$ of the NC schools and $78 \%$ of the NC schools.

One measure of an institution's commitment to diversity is the extent to which its organizational structure includes a diversity committee, council or other formal diversity group. Only $23.1 \%$ of NC private schools had such a group, while $40 \%$ of the SC technical schools had a formal group to address diversity issues. This might be a reflection of differing institutional missions.

In the NC group, $23.1 \%$ had a specific diversity course and of those having such a course, $25 \%$ required it of all students. In the SC technical school group, only $10 \%$ had a specific diversity course and the course was not a required course at any of the institutions.

Diversity training for students, staff and faculty is not uniform. The SC schools reported the availability of diversity training for faculty and staff at $80 \%$ of the schools while NC schools reported $23.1 \%$ for faculty and $30.8 \%$ for staff. Diversity training for students was $30 \%$ for SC schools and $38.5 \%$ for NC schools.

The designation of a Director of Diversity programs occurred at $40 \%$ of the SC schools, but only $15.4 \%$ of the NC schools.

\section{CONCLUSIONS/AREAS FOR FURTHER STUDY}

At least two basic issues arise when addressing Diversity Management. One deals with how diversity management is defined and interpreted. The other includes an examination of how Diversity Management is 
structurally manifested within organizations. The latter is an integral part of an earlier study conducted by Bledsoe/Oatsvall on private colleges and universities in North Carolina. This work expands that study by examining organizational documents and structures in the South Carolina Technical College system. It was an attempt to determine the extent to which diversity management is structurally transparent. The system has sixteen member institutions serving forty-six counties. It is notable that these schools enroll over half of all undergraduates attending a public college or university in South Carolina. (http://www.scteched.tec.sc.us.)

The question becomes, what has been learned from these research efforts? Results from the NCICU and SCTC studies reveal similarities and dissimilarities as might be expected. One explanation may be differences between private and public institutions. Another explanation might be differences in missions with private institutions valuing liberal arts traditions while the public institutions tend to lean toward a technological focus. Sorting out philosophical differences should have little to no impact on creating a cultural setting in which diversity management is embraced to the point that it may be prominently identified within the organizational structure. This latter point leads to answering an important part of the "What has been learned?" question.

The first study by Bledsoe and Oatsvall identified and argued that a manifestation of organizational value of diversity management could be made visible through its structure. This point is verified in the SCTC study. If this is a fact, then a question becomes "So what?" The intriguing part of this question might lead to examining the leadership positions within an organization to determine decision making, strategic initiatives, policies, and key personnel selection. These factors have a distinct impact on how an organization is structured and managed.

Finally, what direction should this research take? The answer may be found in leadership, development of leadership and the practice of leadership. The belief in diversity management may have to be imbedded in all management levels - strategic, tactical and operational. This includes mission, goals, objectives and plans of action.

Faculty and staff leadership are reflected in an organization's structure and these have been examined in this paper. The remaining aspect of student leadership is not reflected in the formal structure of the organization but is an integral part of the diverse community. Student leadership is an avenue for future research.

\section{EMERGING ISSUES FOR FURTHER STUDY}

- $\quad$ Student leadership and diversity

- $\quad$ Single gender vs. coed institutions

- $\quad$ South Carolina private colleges

- $\quad$ North Carolina community college system

- $\quad$ Diversity management and MBO

\section{AUTHOR INFORMATION}

Dr. Tony Bledsoe has taught in the School of Business at Meredith College since 1981. He teaches management, entrepreneurship and business policy. His research interests include women business owners, fraud, diversity management, human resource management and entrepreneurship plus case studies for teaching and learning.

Dr. Rebecca Oatsvall has taught in the School of Business at Meredith College since 1984. She teaches accounting and tax and has directed a Study Abroad program to Italy and Switzerland. Her research interests include internal control, diversity management, entrepreneurship, women business owners and case studies for teaching and learning.

\section{REFERENCES}

1. Astin, A.W. (1996). Involvement in Learning Revisited: Lessons We Have Learned. Journal of College Student Development, 37(2), 123 - 143. 
2. $\quad$ Bledsoe, T. M. \& Oatsvall, R. J. (2008). Diversity Management: A Preliminary Review of Selected Nonprofit North Carolina Independent Colleges \& Universities (NCICU). Journal of Diversity Management, Vol 3, No 1, $7-14$.

3. Cardoza, D. (October 25, 2007). How to Improve Your Recruiting of Minority Faculty Members. The Chronicle of Higher Education. Transcription of live online discussion retrieved 2/28/2008 from http://chronicle.com/live/2007/10/cardoza

4. Garcia, M., Hudgins, C., Musil, C. McT., Nettles, M. T., Sedlacek, W. E., \& Smith D. G. (2002). Assessing Campus Diversity Initiatives: A Guide for Campus Practitioners. Washington, D.C.: Association of American Colleges \& Universities.

5. Gose, B. (2007, September 28). The Professoriate is Increasingly Diverse, but That Didn't Happen by Accident. [Electronic version] The Chronicle of Higher Education, p. B1.

6. Gose, B. (2006, September 29). The Rise of the Chief Diversity Officer. [Electronic version] The Chronicle of Higher Education, pp. B1, B5.

7. Gose, B. (2006, September 29). With a Slew of Assistants, Washington State U. Tackles Diversity in Many Forms. [Electronic version] The Chronicle of Higher Education, p. B1.

8. Gurin, P. (1999) New Research on the Benefits of Diversity in College and Beyond: An Empirical Analysis. [Electronic version] Diversity Digest, Spring, 5.

9. Milem, J., Chang, M., \& Antonio, A. L. (2005). Making Diversity Work on Campus: A Research-Based Perspective. Washington, D.C.: American Colleges and Universities.

10. Schmidt, P. (2007, January 5). Legal Battles Over a Ban on Preferences Heat Up. [Electronic version] The Chronicle of Higher Education, pp. A1, A24.

11. South Carolina Technical College System website, http://www.scteched.tec.sc.us.

12. University of Vienna website (2007). Diversity Management. Retrieved on 2/28/2008 at http://www.univie.ac.at/diversity/php/management.html 
APPENDIX A

\section{List of SC Technical Colleges Surveyed}

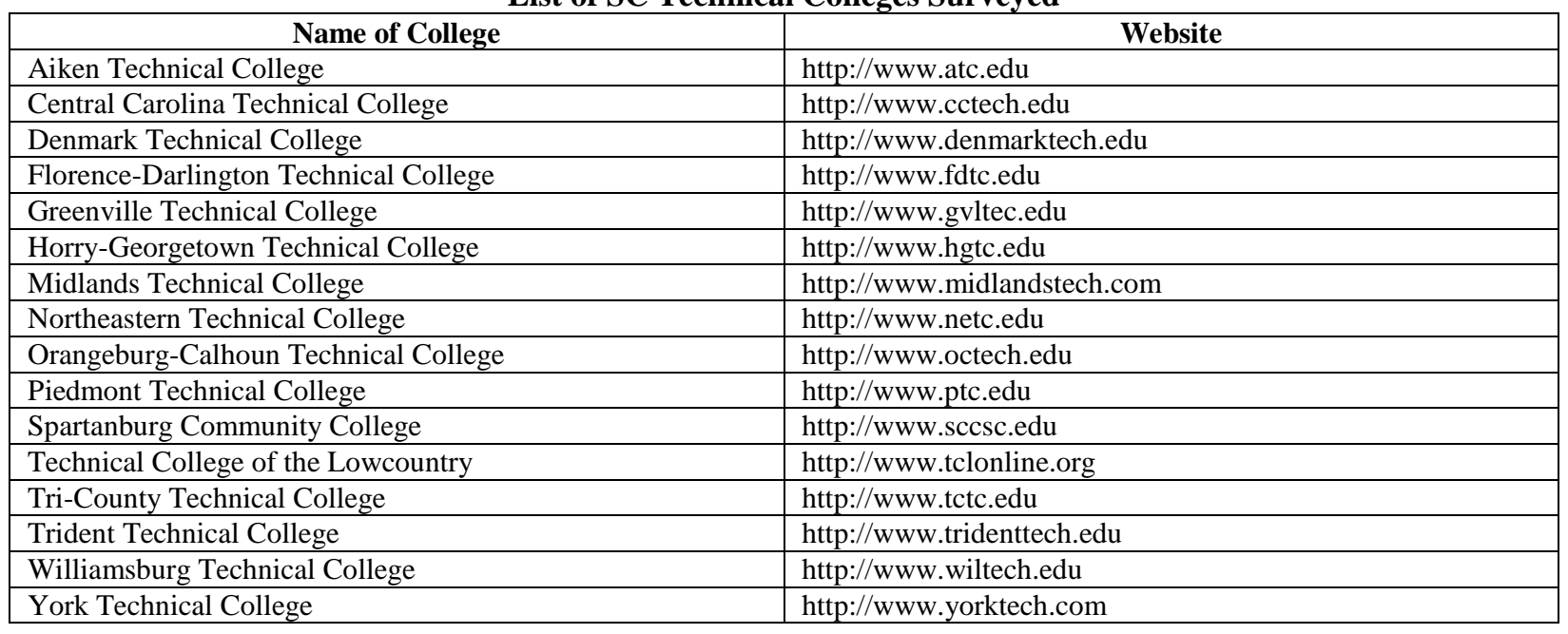

\section{APPENDIX B}

\section{Survey Results SC Technical Schools}

\begin{tabular}{|c|c|c|c|}
\hline & Survey Question & $\%$ Yes & $\%$ No \\
\hline 1. & Does your College Homepage make reference to diversity & $70 \%$ & $30 \%$ \\
\hline 2. & Does your College Mission Statement or Statement of Purpose include the word "diversity?" & $60 \%$ & $40 \%$ \\
\hline 3. & Is diversity implied in your Mission Statement? & $50 \%$ & $50 \%$ \\
\hline 4. & Does your college have published institution-wide goals? & $100 \%$ & $0 \%$ \\
\hline 5. & Is diversity listed as a major goal? & $60 \%$ & $40 \%$ \\
\hline 6. & Are assessment techniques in place for measuring diversity goal effectiveness? & $60 \%$ & $40 \%$ \\
\hline 7. & Does your Academic Catalog include a statement about diversity? & $70 \%$ & $30 \%$ \\
\hline 8. & Do your Recruiting Materials, printed and/or electronic, include diversity information? & $78 \%$ & $22 \%$ \\
\hline 9. & Does your College have a Diversity Committee, Council or other formal Diversity Group? & $40 \%$ & $60 \%$ \\
\hline \multirow[t]{7}{*}{10.} & Which of the following serve on this committee (mark all that apply): & & \\
\hline & Administrators & $24 \%$ & \\
\hline & Faculty & $24 \%$ & \\
\hline & Staff & $24 \%$ & \\
\hline & Students & $0 \%$ & \\
\hline & Other & $4 \%$ & \\
\hline & No Committee & $24 \%$ & \\
\hline 11. & Does your Academic Curriculum include a specific diversity course? & $10 \%$ & $90 \%$ \\
\hline 12. & Is this course a requirement for all students? & $0 \%$ & $100 \%$ \\
\hline 13. & Do you have Diversity Training for Students & $30 \%$ & $70 \%$ \\
\hline 14. & Do you have Diversity Training for Faculty? & $80 \%$ & $20 \%$ \\
\hline 15. & Do you have Diversity Training for Staff? & $80 \%$ & $20 \%$ \\
\hline 16. & Do you have a Diversity Policy in your Student Handbook? & $44 \%$ & $56 \%$ \\
\hline 17. & Do you have a Diversity Policy in your Faculty Handbook? & $50 \%$ & $50 \%$ \\
\hline 18. & Do you have a Diversity Policy in your Staff Handbook? & $50 \%$ & $50 \%$ \\
\hline 19. & Do you have a Designated Director of Diversity Programs for Students? & $40 \%$ & $60 \%$ \\
\hline 20. & Do you have a Designated Director of Diversity Programs for Faculty? & $40 \%$ & $60 \%$ \\
\hline 21. & Do you have a Designated Director of Diversity Programs for Staff? & $40 \%$ & $60 \%$ \\
\hline
\end{tabular}




\section{APPENDIX C}

\section{Survey Results NCICU Schools}

\begin{tabular}{|c|c|c|}
\hline \\
\hline Survey Question & $\%$ Yes & $\%$ No \\
\hline 1. Does your Homepage make reference to diversity? & $30.8 \%$ & $69.2 \%$ \\
\hline 2. Does your Mission Statement include or imply the inclusion of diversity? & $84.6 \%$ & $15.4 \%$ \\
\hline 3a. Do you have published institution-wide goals? & $76.9 \%$ & $23.1 \%$ \\
\hline 3b. If 3a is "yes," is diversity a major goal? & $54.5 \%$ & $45.5 \%$ \\
\hline 4. Does your Undergraduate Academic Catalog include a statement about diversity? & $61.5 \%$ & $38.5 \%$ \\
\hline 5. Do your undergraduate recruiting materials include diversity information? & $69.2 \%$ & $30.8 \%$ \\
\hline 6. Do you have a Diversity Committee, Council or other formal diversity group? & $23.1 \%$ & $76.9 \%$ \\
\hline 7a. Does your undergraduate curriculum include a specific diversity course? & $23.1 \%$ & $76.9 \%$ \\
\hline $7 \mathrm{~b}$. If $7 \mathrm{a}$ is "yes," is the course required of all students? & $25.0 \%$ & $75.0 \%$ \\
\hline 8a. Do you have diversity training for students? & $38.5 \%$ & $61.5 \%$ \\
\hline 8b. Do you have diversity training for faculty? & $23.1 \%$ & $76.9 \%$ \\
\hline 8c. Do you have diversity training for staff? & $30.8 \%$ & $69.2 \%$ \\
\hline 9a. Do you have a diversity policy in your student handbook? & $38.5 \%$ & $61.5 \%$ \\
\hline 9b. Do you have a diversity policy in your faculty/staff handbooks? & $23.1 \%$ & $76.9 \%$ \\
\hline 10a. Do you have a designated Director of Diversity programs for students? & $15.4 \%$ & $84.6 \%$ \\
\hline 10b. Do you have a designated Director of Diversity programs for faculty/staff? & $7.7 \%$ & $92.3 \%$ \\
\hline
\end{tabular}

